\title{
Production Biomolecule with Inhibitory Activity against Gram-negative Bacteria Isolated from Faeces of Broilers and Swine
}

\author{
Sidnei Emílio Bordignon Junior, Mitiyo Fukuda Miyaoka, Michele Rigon Spier, Rosália \\ Rubel, Vanete Thomaz Soccol and Carlos Ricardo Soccol* \\ Programa de Pós-Graduação em Processos Biotecnológicos; Universidade Federal do Paraná; $81531-990$ \\ Curitiba - PR - Brasil
}

\begin{abstract}
The aim of this study was to investigate the potential of lactic acid bacteria, bacilli and yeasts isolates to produce antimicrobial substances, especially against Gram-negative bacteria isolated from the animal faeces, searching for a new alternative to control the enteritis diseases in animal health. Evaluations were performed by microdilution in broth using crude extract obtained from the cultivation of 272 strains against Escherichia coli, S. Typhimurium, S. Enteritidis and Pseudomonas aeruginosa. Thirty-five lactic acid bacteria presented some antimicrobial action. One Lactobacillus isolate, named FLPB-1, was selected to studies the kinetics of the production. An important increase in the production was obtained when the producer strain had cell-to-cell contact with a Gram-positive inducer culture. Maximal production of antimicrobial compounds was obtained in the beginning of stationary phase and the addition of urea in the medium increased the inhibition rate.
\end{abstract}

Key words: antimicrobial, enteritis, lactic acid bacteria, bacteriocin.

\section{INTRODUCTION}

The poultry production chain has constant advances in intensive management of animals and operations technology from advances in genetics, nutrition and animal health. Higher quality products and food security ensure the credibility. However, the intensification of the production may cause an increase in pathological load and increasing health problems. Currently, enteritis and diarrhea are serious problems in broilers, especially in newborns (Almeida et al., 2007). These intestinal infections are caused by the Gram-negative bacteria, especially Escherichia coli, Pseudomonas and Salmonella, which are more prevalent in the early life of poultry and, later, in situations of bacterial flora imbalance or immunosuppression (Porter, 1998).

After the discovery of antibiotics and their continuous supply by nutrition in recent decades, the control of enteritis in broilers production has been possible. However, bacterial resistance to drugs quickly grew and now represents a latent concern by the world organizations and the population itself. Besides, the acquired bacterial resistance and its complications in the management of animals, and the transfer of

*Author for correspondence: soccol@ufpr.br 
pathogenic resistance to human could create chaos to global public health.

Restrictions to the use of antibiotics in animal nutrition are common practices in many countries for poultry meat, especially in European Union. The reasons for these restrictions are consumer protection and healthier eating. This situation motivates the search for new efficient technologies against intestinal infections in animals, especially in producing countries. Brazil represents the world's largest export market for chicken meat and, according to projections, will have an annual growth rate of production of $3.64 \%$, and in 2019/2020 will be responsible for $70 \%$ of exportation from the world market (Age / Mapa, 2010).

As an alternative to the use of antibiotics in meat production, it is necessary to use active substances capable of promoting weight gain, enable the desired balance of organisms in the intestinal microflora and able to guarantee bacterial sensibility. In this context, the lactic acid bacteria appear as an interesting alternative for this application due to their flexibility for use as a probiotic organism, by the use of cells to adhesion, colonization and organic acids production in the intestinal tract, and also for the synthesis of low molecular weight peptides with bactericidal or bacteriostatic effects - the bacteriocins (Parada et al., 2007; Lin et al, 2007).

The aim of this study was to investigate the potential of isolates belonging to the strains bank of the Bioprocess Engineering and Biotechnology Department at Universidade Federal do Paraná (UFPR, Brazil) to produce antimicrobial compounds capable of inhibiting the Gramnegative pathogen growth isolated from the animal faeces, and finally, perform a study on their antimicrobial substance production.

\section{MATERIALS AND METHODS}

\section{Strains and Culture Conditions}

A total of 272 microorganisms were subjected to evaluation for their potential as producer of antimicrobial substance. Two hundred one strains were lactic acid bacteria, seven were Bacillus sp. and 64 were yeasts strains. The origin of the strains was wide and represented the part of the intestinal tract and faeces of humans and animals, microflora of the plants and fruits, silage and cured sausage. Four Gram-negative pathogenic bacteria isolated from the animal faeces (swine and broilers) in the clinical cases of diarrhea were used as target microorganisms for antimicrobial evaluations (Escherichia coli, Salmonella Enteritidis, Salmonella Typhimurium and Pseudomonas aeruginosa). The lactic acid bacteria cultivation was carried out in MRS broth at $30^{\circ} \mathrm{C}$, the Gram-positive bacilli in Nutrient broth at $28^{\circ} \mathrm{C}$, the yeasts in YM broth (Yeast Malt) at $28^{\circ} \mathrm{C}$ and the pathogens in BHI broth (Brain Heart Infusion) at $37^{\circ} \mathrm{C}$. All the cultures were stored at $-80^{\circ} \mathrm{C}$ with $3 \%(\mathrm{v} / \mathrm{v})$ glycerol for preservation.

\section{Inhibitory Activity Assay}

The inhibitory activity was evaluated in the crude extract obtained by the cultivation of the strains in specific growth broth for $24 \mathrm{~h}$ and, then the cells were removed by centrifugation $(808 \mathrm{xg} / 20$ minutes). The supernatants were adjusted to $\mathrm{pH}$ 6.5 using $1 \mathrm{~N} \mathrm{NaOH}$ solution and then filtered through a $0.22 \mu \mathrm{m}$ membrane. The antimicrobial activity was tested in micro-dilution broth plates, based on the method described by Toba et al. (1991). The method was adapted to assay in liquid broth with uniforms volumes from Mueller-Hinton broth and crude extract (sample). The results were obtained by reading of the optical density (absorbance) at $630 \mathrm{~nm}$ on a spectrophotometer type player ELISA (BioTek, model Power Wave $\mathrm{XS}, \mathrm{KC}$ Junior program) in samples prepared on plates with 96 wells. Increased permeability of the outer membrane of target microorganisms was evaluated by the use of $1 \mathrm{mM}$ solution of Ethylene Diamine Tetraacetic Acid (EDTA) in comparison of results without EDTA. A solution containing 10,000 Arbitrary Units per milliliter (AU / mL) nisin (Nisaplin, Sigma) diluted in $0.02 \mathrm{~N} \mathrm{HCl}$ was used as the control of inhibition (positive control). Sterile broth (MRS, Nutrient or YM) were used as growth control (negative control) of the target organism in micro-dilution plates. The pathogens inoculate were standardized after enrichment for $12 \mathrm{~h}$ and complied with the Performance Standards for Antimicrobial Disk Susceptibility Tests Approved Standard $-8^{\text {th }}$ Edition (NCCLS, 2003). The inoculum represented a population of approximately $1 \times 10^{6} \mathrm{CFU} / \mathrm{mL}$, or $2 \times 10^{4} \mathrm{CFU} /$ well. The optical density $\left(\mathrm{OD}_{630}\right)$ readings were taken every $2 \mathrm{~h}$, starting $8 \mathrm{~h}$ after inoculation until $18 \mathrm{~h}$. All the tests were performed in triplicate. The results of inhibitory percentage were obtained by the equation described by Portella et al. (2009): 
$I(\%)=\left[\frac{\operatorname{Inc} O D_{630} \text { control - Inc } O D_{630} \text { sample }}{\operatorname{Inc} O D_{630} \text { control }}\right] \times 100$

Where: I $(\%)=$ percentage of inhibition of the sample in relation to the growth control; Inc. OD Control = Increment in optical density of the growth control; Inc. OD Sample = Increment in optical density of the sample.

\section{Sensibility to antibiotics and nisin}

Escherichia coli, Salmonella Enteritidis, Salmonella Typhimurium and Pseudomonas aeruginosa were evaluated to antibiotic sensibility against Amikacin, Ampicillin/Sulbactam, Aztreonam, Cefalotin, Cefepime, Cefotaxime, Cefoxitin, Ceftazidime, Ciprofloxacin, Colistin, Ertapenem, Gentamicin, Imipenem, Meropenem, Piperacillin/Tazobactam and Tigecycline. The methodology used was automated culture according to manual from American Society for Microbiology (Murray et al, 2007) and Clinical and Laboratory Standards Institute (CLSI, 2010). The assays were conducted in the Clinical Hospital of the Federal University of Paraná, Brazil.

The minimal inhibitory concentration (MIC) of nisin (Nisaplin, Sigma) for each target organism was determined using solutions with 200, 300, 400,500 and $600 \mathrm{AU}$ (total concentration) in interaction with cells during the antimicrobial assays that were performed as describe above.

\section{Kinetic and Induction studies}

The standard culture, Staphylococcus aureus ATCC 25923, was applied for induction studies.
After $12 \mathrm{~h}$ of initial growth of producer strain, the second culture was added at $10 \%(\mathrm{v} / \mathrm{v})$ inoculum. Samples have been withdrawn every 12 hour until it cached 48 hour of fermentation and crude extracts were prepared. The antimicrobial assays were performed as described above to determine the inhibitory rate in percentage about the growth control.

\section{Nitrogen supplementation}

Urea was used as additional source of nitrogen in culture medium to evaluate its influence on the production of antimicrobial compounds at (\%) $0.25,0.50,0.75$ and $1.00 \%$. The crude extracts were prepared and the antimicrobial assays were performed as describe previously to determine the inhibitory rate

\section{RESULTS AND DISCUSSION}

Antimicrobial assays revealed 35 isolates from lactic acid bacteria as potential producers of antimicrobial substance with decrease of optical density of $50 \%$ or higher on at least one target organism in exponential phase of growth (data not shown). The inhibitory effect was not due to the action of organic acids, because the crude extract was neutralized before the evaluations. No inhibitory potential was observed on yeasts and Bacillus genus. Among the 35 lactic acid bacteria, ten showed potential because they retarded the development of pathogens for longer and / or the broader spectrum of activity (Table 1). Increase of inhibitory rate was observed when EDTA was used to sensitize the outer membrane of the target cells (Table 1).

Table 1 - Inhibitory rate $(\%)$ of 10 lactic acid bacteria selected with greater potential production of antimicrobial substances.

\begin{tabular}{|c|c|c|c|c|c|c|c|c|}
\hline \multirow{3}{*}{$\begin{array}{l}\text { Antimicrobial } \\
\text { producer } \\
\text { bacteria code }\end{array}$} & \multicolumn{8}{|c|}{ Inhibitory rate on target organism } \\
\hline & \multicolumn{2}{|c|}{ Escherichia coli } & \multicolumn{2}{|c|}{ Salmonella Enteritidis } & \multicolumn{2}{|c|}{ Salmonella Typhimurium } & \multicolumn{2}{|c|}{ Pseudomonas aeruginosa } \\
\hline & $\begin{array}{l}\text { without } \\
\text { EDTA }\end{array}$ & $\begin{array}{c}\text { with } \\
\text { EDTA }\end{array}$ & $\begin{array}{l}\text { without } \\
\text { EDTA }\end{array}$ & $\begin{array}{c}\text { with } \\
\text { EDTA }\end{array}$ & $\begin{array}{l}\text { without } \\
\text { EDTA }\end{array}$ & $\begin{array}{c}\text { with } \\
\text { EDTA }\end{array}$ & $\begin{array}{l}\text { without } \\
\text { EDTA }\end{array}$ & $\begin{array}{c}\text { with } \\
\text { EDTA }\end{array}$ \\
\hline 024 & - & - & $52 \%$ & $57 \%$ & - & - & - & - \\
\hline 027 & - & - & $51 \%$ & $57 \%$ & $54 \%$ & $77 \%$ & $28 \%$ & $56 \%$ \\
\hline 037 & $17 \%$ & $29 \%$ & - & - & $56 \%$ & $71 \%$ & $100 \%$ & $100 \%$ \\
\hline 038 & - & - & $54 \%$ & $80 \%$ & - & - & - & - \\
\hline 040 & - & - & - & - & $78 \%$ & $87 \%$ & $100 \%$ & $100 \%$ \\
\hline 043 & $40 \%$ & $84 \%$ & - & - & - & - & - & - \\
\hline 061 & - & - & - & - & $90 \%$ & $99 \%$ & $22 \%$ & $71 \%$ \\
\hline 095 & $95 \%$ & $99 \%$ & $28 \%$ & $39 \%$ & - & - & - & - \\
\hline 129 & - & - & - & - & $96 \%$ & $100 \%$ & $98 \%$ & $100 \%$ \\
\hline 224 & $100 \%$ & $100 \%$ & $60 \%$ & $100 \%$ & $26 \%$ & $52 \%$ & - & - \\
\hline
\end{tabular}


Generally, the antimicrobial assays presented some difficulties in standardization because no single method could be applied to all the antimicrobial compounds, thus, the methodologies followed the principles used in antibiotic research (Andrews, 2001). The use of micro-dilution plate is adequate in screening of a large number of samples because it is economical and less labour intensive. Moreover, the use of a liquid medium for the cellular growth allows the immediate active substance-cell interaction, increasing the sensitivity of the method, when, for example, in comparison with the traditional well diffusion assay, which depends on the diffusion rate on agar (Du Toit and Rautenbach, 2000). The sensibility in inhibition determined by a spectrophotometric method is more accurate than physically measuring the zones of inhibition, because it is free of human errors. Other sources of errors in the well diffusion assay can involve the plate's preparation and the composition of culture medium (Alves et al., 2008).

Lactic acid bacteria (LAB) are widely recognized as antimicrobial substances producers and those of proteinaceus nature, the bacteriocins, are of great interest for industrial application in the control of food spoilage, especially for the meat and dairy products (Sivakumar et al., 2010; Bordignon Junior et al, 2010; Abrams et al, 2011). Usually, the spectrum of action by LAB's is more effective in closed related species; however, some bacteriocins or bacteriocins-like substances are also active against Gram-negative bacteria, such as Escherichia coli and Salmonella Typhimurium (Gong et al., 2010), Pseudomonas aeruginosa and Klebsiella pneumoniae (De Kwaadsteniet et al., 2005).

The antimicrobial assays showed an interesting potential by the selected isolated in this study because several LAB presented inhibitory capacity against Gram-negative strains. Only the inhibition results higher than 50\% was considered satisfactory in the screening (Rojo-Besares et al., 2006).

The use of EDTA in antimicrobial assays helps to potentiate the action and get to clearest inhibition results. Probably the EDTA caused a profound effect on the outer membrane permeability of the Gram negative enteric bacteria, and the sensibility of organisms was affected; however, it was not lethal. A treatment with $1 \mathrm{mM}$ of EDTA could be used to introduce the macromolecules and hydrophobic compounds without affecting the cell viability. It is possible by sequestering the stabilizing divalent cations of the outer membrane (Vaara, 1992).

The susceptibility profile by antibiotics from four Gram-negative bacteria used in this study was applied as the pathogens had been isolated from faeces of dead animals that received antibacterial agents for the intestinal infections control. The results from antibiogram are presented in Table 2, which revealed the same sensitivity profile between $S$. enteritidis and $S$. typhimurium, with proved resistance against amikacin, cefalotin, cefoxitin and gentamicin. The resistance to ampicillin, cefalotin, cefatoxime, cefoxitin and tigecycline was detected in Pseudomonas aeruginosa no resistance was observed in $E$. coli for the same drugs. Zhao et al. (2007) characterized the multidrug resistance to antibiotics in 308 Salmonella stain isolated from the animal diagnostic samples and found the highest rate of resistance for the isolates from swine $(92 \%)$, followed by turkey $(91 \%)$, cattle (77\%), chicken $(68 \%)$ and horse $(20 \%)$. For amikacin $(\geq 32 \mu \mathrm{g} / \mathrm{mL})$, there was no resistance among the isolates from chickens and only $1 \%$ for the swine isolates. For cefalotin $(\geq 32 \mu \mathrm{g} / \mathrm{mL})$, there was $23 \%$ resistance for chicken isolates and $15 \%$ for swine isolates. For cefoxitin $(\geq 32$ $\mu \mathrm{g} / \mathrm{mL}$ ), the resistance was $14 \%$ to the chicken and $6 \%$ to swine, and for gentamicin $(\geq 16 \mu \mathrm{g} / \mathrm{mL})$, it was $9 \%$ to the chicken isolates and $8 \%$ to the isolates from the swine. For $71 \%$ isolates belonging to $S$. typhimurium the resistance was to 5-8 antibiotics tested, which was a serious concern. This situation becomes more critical because it reduces the possibilities of therapeutic treatments to invasive infections, both for the animals and humans, which often use the same drugs. The inhibitory potential of nisin, the only bacteriocin recognized as GRAS and applied in the industrial process as natural preservative in cheese and sausage surface, also was evaluated against the four Gram-negative bacteria. All the strains were sensitive at different concentration of nisin solution and the minimal inhibitory concentration (MIC) was $S$. enteritidis $(123 \mathrm{AU} / \mathrm{mL}), S$. typhimurium (493 AU/mL), $E$. coli and $P$. aeruginosa (1.111 AU/mL). 
Table 2 - Antibiogram assay to Gram-negative bacteria isolated from animal faeces.

\begin{tabular}{lcccc}
\hline Antibiotic tested & $\begin{array}{c}\text { Escherichia } \\
\text { coli }\end{array}$ & $\begin{array}{c}\text { Salmonella } \\
\text { Enteritidis }\end{array}$ & $\begin{array}{c}\text { Salmonella } \\
\text { Typhimurium }\end{array}$ & $\begin{array}{c}\text { Pseudomonas } \\
\text { aeruginosa }\end{array}$ \\
\hline Amikacin & $\mathrm{S}$ & $\mathrm{R}(\leq 2 \mu \mathrm{g} / \mathrm{mL})$ & $\mathrm{R}(\leq 2 \mu \mathrm{g} / \mathrm{mL})$ & $\mathrm{S}$ \\
Ampicillin/Sulbactam & $\mathrm{S}$ & $\mathrm{S}$ & $\mathrm{S}$ & $\mathrm{R}(\geq 32 \mu \mathrm{g} / \mathrm{mL})$ \\
Aztreonam & $\mathrm{S}$ & $\mathrm{S}$ & $\mathrm{S}$ & $\mathrm{n} . \mathrm{a}$. \\
Cefalotin & $\mathrm{S}$ & $\mathrm{R}(\leq 2 \mu \mathrm{g} / \mathrm{mL})$ & $\mathrm{R}(\leq 2 \mu \mathrm{g} / \mathrm{mL})$ & $\mathrm{R}(\geq 64 \mu \mathrm{g} / \mathrm{mL})$ \\
Cefepime & $\mathrm{S}$ & $\mathrm{S}$ & $\mathrm{S}$ & $\mathrm{S}$ \\
Cefotaxime & $\mathrm{S}$ & $\mathrm{S}$ & $\mathrm{S}$ & $\mathrm{R}(32 \mu \mathrm{g} / \mathrm{mL})$ \\
Cefoxitin & $\mathrm{S}$ & $\mathrm{R}(\leq 4 \mu \mathrm{g} / \mathrm{mL})$ & $\mathrm{R}(\leq 4 \mu \mathrm{g} / \mathrm{mL})$ & $\mathrm{R}(\geq 64 \mu \mathrm{g} / \mathrm{mL})$ \\
Ceftazidime & $\mathrm{S}$ & $\mathrm{S}$ & $\mathrm{S}$ & $\mathrm{S}$ \\
Ciprofloxacin & $\mathrm{S}$ & $\mathrm{S}$ & $\mathrm{S}$ & $\mathrm{S}$ \\
Colistin & $\mathrm{S}$ & $\mathrm{S}$ & $\mathrm{S}$ & $\mathrm{S}$ \\
Ertapenem & $\mathrm{S}$ & $\mathrm{S}$ & $\mathrm{S}$ & $\mathrm{n} . \mathrm{a}$. \\
Gentamicin & $\mathrm{S}$ & $\mathrm{R}(\leq 1 \mu \mathrm{g} / \mathrm{mL})$ & $\mathrm{R}(\leq 1 \mu \mathrm{g} / \mathrm{mL})$ & $\mathrm{S}$ \\
Imipenem & $\mathrm{S}$ & $\mathrm{S}$ & $\mathrm{S}$ & $\mathrm{S}$ \\
Meropenem & $\mathrm{S}$ & $\mathrm{S}$ & $\mathrm{S}$ & $\mathrm{S}$ \\
Piperacillin/Tazobactam & $\mathrm{S}$ & $\mathrm{S}$ & $\mathrm{S}$ & $\mathrm{S}$ \\
Tigecycline & $\mathrm{S}$ & $\mathrm{S}$ & $\mathrm{S}$ & $\mathrm{R}(\geq 8 \mu \mathrm{g} / \mathrm{mL})$ \\
\hline
\end{tabular}

$(\mathrm{R}=$ resistant; $\mathrm{S}$ = sensible; n.a. = not available).

Among all the strains with positive results in the screening, the number 27, a Lactobacillus sp. named FLPB-1, was selected for further studies as it demonstrated greater regularity on antimicrobial production between different batches evaluated (data not shown).

The stimulus on antimicrobial production by FLPB-1 was carried when the fermentative process occurred in co-cultivation with Staphylococcus aureus ATCC 25923. Strain FLPB-1 demonstrated ability to reduce the population of enteric pathogens E. coli, Salmonella typhimurium, $S$. enteritidis and $P$. aeruginosa. In comparison between the simple cultivation and co-cultivation, at $14 \mathrm{~h}$ of assay, the inhibitory potential increased from 57 to $98 \%$ for S. enteritidis 77 to $98 \%$ for $S$. typhimurium, and 56 to $88 \%$ for $P$. aeruginosa. The inhibitory rate also was observed against E. coli, with $81 \%$ inhibition. Figure 1 shows the inhibition data obtained by the action of crude extract from FLPB-1 compared with the controlled growth of each target organism (without the addition of crude extract from FLPB-1).
The co-culture-induced technique was related by Ruiz-Barba et al. (2010) as necessary for bacteriocin production due the cell-to-cell contact between the producing strain and inducing the bacteria. The authors postulated also that the presence of specific bacteria was recognized by the strains, such Lactobacillus sp., as an environmental stimulus to switch a specific adaptive response and, as a consequence, the synthesis of bactericin occurred. In this study, the results after co-cultivation were very significant because the inhibitory potential increased in all the cases.

Lactobacilli have great potential for antimicrobial production such as bacteriocins. L. acidophilus has been reported for the production of acidocin and lactacin B and F (Parada et al., 2007). L. fermentum, isolated from the gastrointestinal digestive tract and mucosa in the swine and poultry have been described as potential probiotic organisms and inhibitors of enteric pathogens of these animals, especially against E. coli, Salmonella spp., Shigella sonnei, and with less efficiency, enterotoxigenic Staphylococcus aureus (Lin et al., 2007). 
(A)

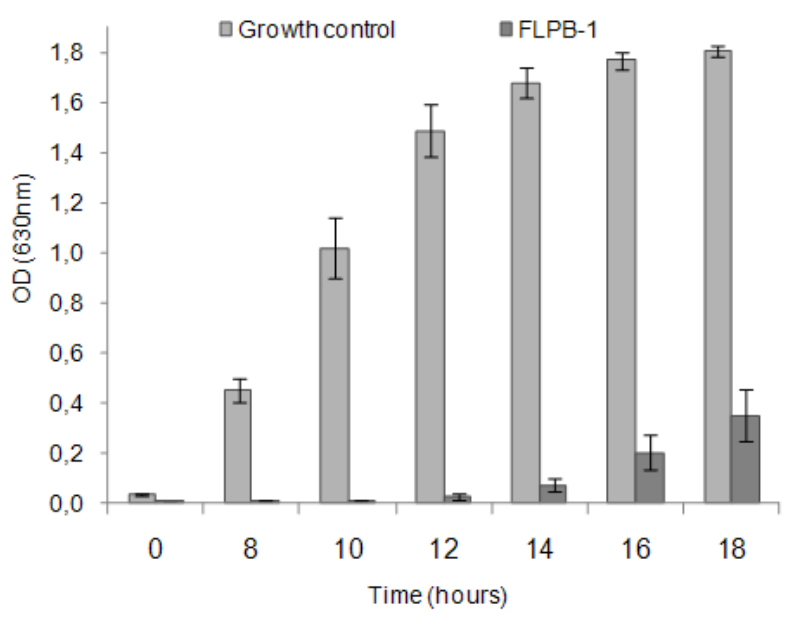

(C)

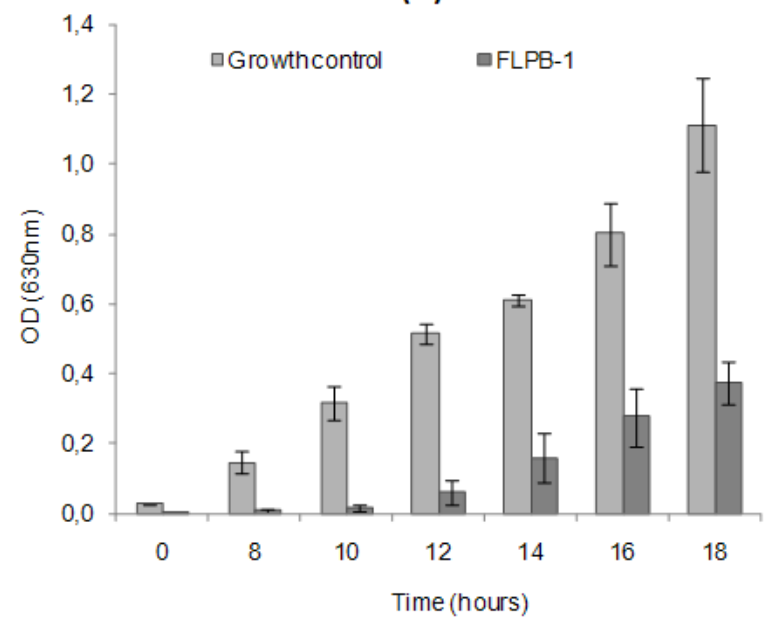

(B)

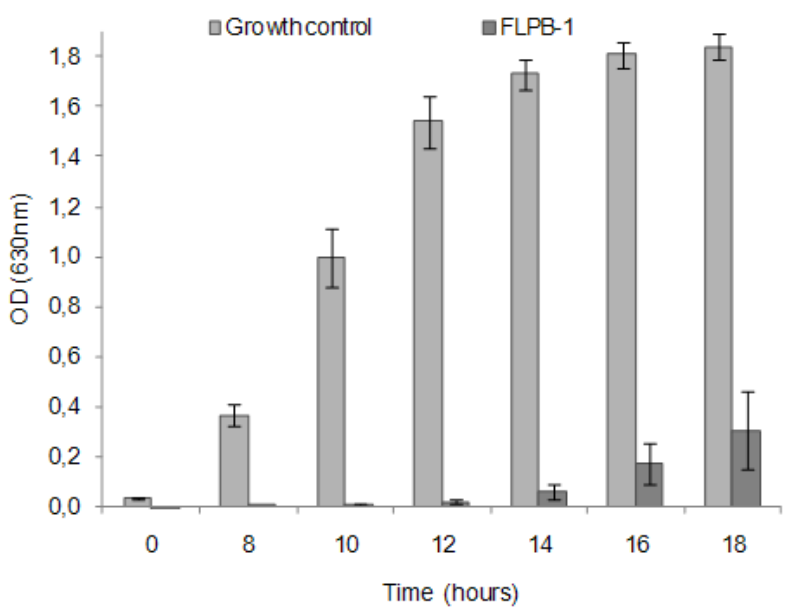

(D)

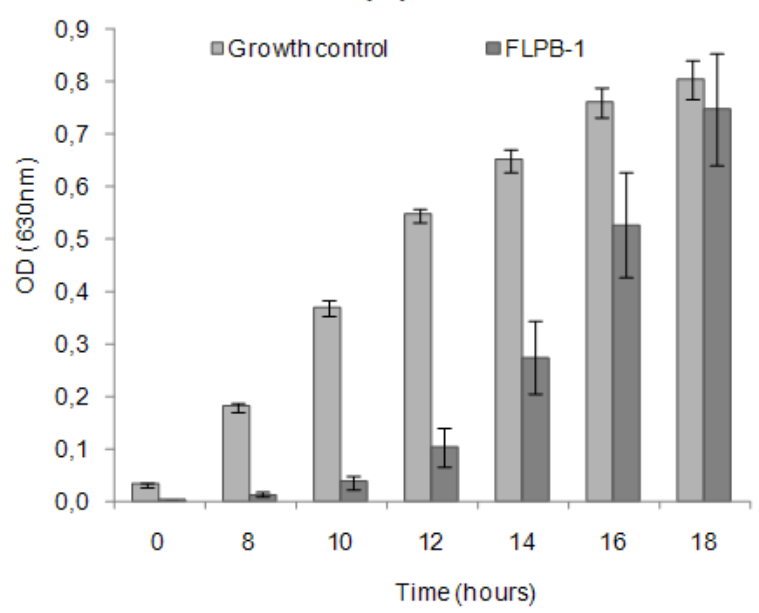

Figure 1 - Crude extract action obtained by co-cultivation between FLPB-1 lactic acid bacteria and Staphylococcus aureus ATCC 25923. (A) Antimicrobial activity against Salmonella Typhimurium; (B) Antimicrobial activity against Salmonella Enteritidis; (C) Antimicrobial activity against Pseudomonas aeruginosa; (D) Antimicrobial activity against Escherichia coli. Both experiments were performed until 18 hours of microorganism exposition on extract containing antimicrobial substance.

Studies about kinetic of antimicrobial production in co-cultivation system showed that the maximal production occurred after about 36 to $48 \mathrm{~h}$ fermentation (Figure 2). It represented the beginning of the stationary phase of growth in FLPB-1 and coincided with the greater cellular density period. Several studies have shown that the antimicrobial compounds production, such as bacteriocins, are dependent on high biomass in the medium because this is an important factor related to signalization of physiological responses able to active operons required for the synthesis, transport and regulations these compounds in LABs (Maldonado et al., 2003; Sturme et al., 2007). Other studies have reported the optimal production in similar periods. A bacteriocin produced by $L$. plantarum had highest concentration after $29 \mathrm{~h}$ of cultivation, between final exponential phase and beginning of the stationary phase of growth. The antimicrobial compound was classified then as a primary metabolite (Todorov, 2008). In other study, the maximal amounts of bacteriocin ST5Ha 
was recorded after $42-45 \mathrm{~h}$ of growth in MRS broth, and quickly decreased after $45 \mathrm{~h}$ of fermentation (Todorov et al., 2010). In this study, all inhibition rates decreased after $48 \mathrm{~h}$ of fermentation. This behavior could be linked to the action of extracellular proteases in the medium, and also due the adsorption of active compounds on the target cells, decreasing the activity. The adsorption potential has been studied as an alternative to recover the bacteriocins from the supernatant (Abrams et al., 2011; De Kwaadsteniet et al., 2005; Todorov et al., 2007).

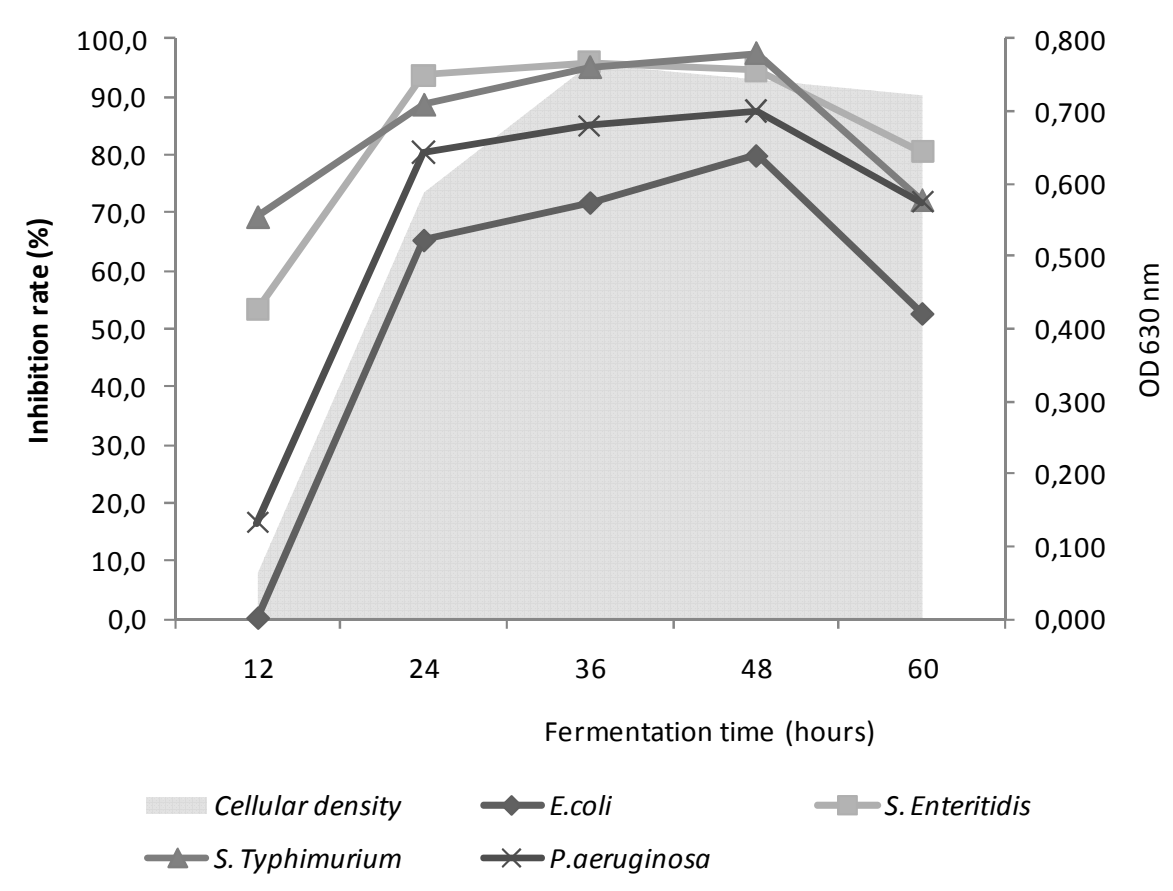

Figure 2 - Kinetic of antimicrobial production by FLPB-1 in co-cultivation.

Lactic acid bacterium traditionally requires complex nutrition for the growth. The MRS supplies this condition and is good medium to neutralize the lactic acid produced and improve the cell density ( $\mathrm{Li}$ et al., 2002). However, the amounts of antimicrobial compounds in the fermentation supernatants are normally low and require studies to increase the production and concentrate the extract by purification protocols. Thus, the first step in this regard would be to increase the production by medium composition. The supplementation of external nitrogen may be important to get highest concentrations of antimicrobial compounds. Todorov and Dicks (2009) observed 2-fold in the production of bacteriocin after the addition of some nitrogen source in MRS media. However, the sources studied in this work such peptone, yeast extract or meat extract, might contain proteases that would degrade the proteinaceus nature of antimicrobial substance. Moreover, the supplementation of the rich organic sources increases the cost of production and also brings difficulties in their purification ( $\mathrm{Li}$ et al., 2002). Therefore, in this study, the influence on antimicrobial activity by the additional source of nitrogen was evaluated using urea. The results are presented in Table 3.

The addition of urea was positive at 0.5 and $0.75 \%$. The antimicrobial activity was better for $E$. coli and $P$. aeruginosa, in comparison to control. The dosage of $1.0 \%$ urea seemed to have been excessive for the fermentation, because the activity was totally lost, except for $S$. Typhimurium, where a half of initial activity remained. 
Table 3 - Inhibitory rate according treatments of urea in culture medium composition.

\begin{tabular}{lcccc}
\hline Treatments & Escherichia coli & $\begin{array}{c}\text { Salmonella } \\
\text { Enteritidis }\end{array}$ & $\begin{array}{c}\text { Salmonella } \\
\text { Typhimurium }\end{array}$ & $\begin{array}{c}\text { Pseudomonas } \\
\text { aeruginosa }\end{array}$ \\
\hline Control (without urea) & $81.0 \%$ & $98.8 \%$ & $98.1 \%$ & $88.0 \%$ \\
Urea 0.25\% & $66.5 \%$ & $90.4 \%$ & $90.3 \%$ & $64.3 \%$ \\
Urea 0.50\% & $91.1 \%$ & $96.5 \%$ & $98.5 \%$ & $92.0 \%$ \\
Urea 0.75\% & $90.0 \%$ & $98.3 \%$ & $94.8 \%$ & $88.4 \%$ \\
Urea 1.00\% & n.o. & n.o. & $55.8 \%$ & n.o. \\
\hline
\end{tabular}

*n.o. = not observed inhibitory effect.

The LAB isolates showed higher potential for antimicrobial compounds synthesis than the yeasts and Bacillus isolates. The inhibition rates observed were high and represented an important potential because all the target strains were Gram-negative bacteria and were severe pathogens on animal meat chain productive. The use of EDTA at $1 \mathrm{mM}$ was positive in antimicrobial assays and did not have influence as inhibitor agent.

The addition of $S$. aureus ATCC 25923 as inducer culture on fermentative process of FLBP-1 showed increased production of inhibitory substance, evidenced by increased inhibitory rates against the pathogens. The antibiogram revealed that $E$. coli was the most sensetive between the Gram-negative isolates studied, whereas other three presented resistance for at least four antibiotics tested. On the other hand, the sensitivity of nisin was higher for Salmonella Enteritidis and Typhimirium than for $E$. coli. These results were closer with those obtained by crude extract from FLPB-1, confirming the distinct mode of action by each antimicrobial substance.

The maximal production of active substances was observed at the beginning of the stationary phase of growth in co-cultivation, where the cell density was maximum, with increase in the production by addition of $0.5-0.75 \%(w / v)$ urea in MRS.

\section{ACKNOWLEDGEMENTS}

This work was supported by Coordenação de Aperfeiçoamento de Pessoal de Nível Superior CAPES - Brazil and Federal University of ParanáUFPR. We thank to Hospital das Clínicas Curitiba - Paraná for its contribution.

\section{REFERENCES}

Abrams, D. et al. (2011), Characterization of bacPPK34 a bacteriocin produced by Pediococcus pentosaceus strain K34 isolated from "Alheira". Food Control, 22, 940-946.

Age/Mapa. (2010), Assessoria de Gestão Estratégica. Ministério da Agricultura, Pecuária e Abastecimento. Projeções do Agronegócio. Brasília: MAPA.

Almeida, F. S. et al. (2007), Diarréia Suína: estudo da etiologia, virulência e resistência a antimicrobianos de agentes isolados em leitões na região de Ribeirão Preto-SP, Brasil. ARS Veterinaria, 23, 151-157.

Alves, E.G. et al. (2008), Estudo Comparativo de Técnicas de Screening para Avaliação da Atividade Anti-Bacteriana de Extratos Brutos de Espécies Vegetais e de Substâncias Puras. Quim. Nova, 31, 1224-1229.

Andrews, J. M. (2001), Determination of minimum inhibitory concentrations. J. Antimicrob. Chemother, 48, 5-16.

Bordignon Junior, S. E.; Gatti, D. J.; Gelinski, J. M. L. N. (2010), Antagonistic activity of lactic acid bacteria isolated from artisan italian salami. Braz. J. Food Technol., 13, 18-22.

CLSI Clinical Laboratories Standards Institute. (2010), Performance Standards for Antimicrobial Susceptibility Testing. Pennsylvania, USA.

De Kwaadsteniet, M.; et al. (2005), Characterization of a 3944 Da bacteriocin, produced by Enterococcus mundtii ST15, with activity against Gram-positive and Gram-negative bacteria. Int. J. Food Microbiol., 105, 433- 444 .

Du Toit, E.A.; Rautenbach, M. (2000), A Sensitive Standardised Micro-gel Well Diffusion Assay for the Determination of Antimicrobial Activity. $J$. Microbiol. Methods, 42, 159-165.

Gong, H.S.; Meng, X.C.; Wang, H. (2010), Plantaricin MG activity against Gram-negative bacteria produced by Lactobacillus plantarum KLDS1.0391 isolatedfrom "Jiaoke", a traditional fermented cream from China. Food Control, 21, 89-96. 
Li, C. et al. (2002), Optimization of a cultural medium for bacteriocin production by Lactococcus lactis using response surface methodology. J. Biotechnol., 93, 27-34.

Lin, W. H. et al. (2007), Different probiotic properties for Lactobacillus fermentum strains isolated from swine and poultry. Anaerobe, 13, 107-113.

Maldonado, A.; Jiménes-Días, R.; Ruiz-Barba, J. L. (2003), Induction of Plantaricin Production in Lactobacillus plantarum NC8 after Coculture with Specific Gram-Positive Bacteria Is Mediated by an Autoinduction Mechanism. J. Bacteriol., 186, 15561564.

Murray, R. P. et al. (2007), Manual of Clinical Microbiology, 9 ed., v. 1. Washington DC: ASM

NCCLS. Performance Standards for Antimicrobial Disk Susceptibility Tests. (2003) Approved Standard Eighth Edition. NCCLS document M2-A8. Pennsylvania, USA.

Parada, J.L.; Caron, C.R.; Medeiros, A.B.; Soccol, C.R. (2007), Bacteriocins from lactic acid bacteria: purificacion, properties and use as biopreservatives. Braz. Arch. Biol. Technol., 50, 521-542.

Portella, A.C.F. et al. (2009), Modelling Antagonic Effect of Lactic Acid Bacteria Supernatants on Some Pathogenic Bacteria. Braz. Arch. Biol. Technol., 52, 29-36.

Porter, R. E. JR. (1998), Bacterial Enteritides of Poultry. Poultry Sci., 77, 1159-1165.

Rojo-Besares, B. et al. (2007), Coculture-inducible bacteriocin activity of Lactobacillus plantarum strain J23 isolated from grape must. Food Microbiol., 24, 482-491.

Ruiz-Barba, J. L. et al. (2010), Coculture with specific bacteria enhances survival of Lactobacillus plantarum NC8 an autoinducer-regulated bacteriocin producer, in olive fermentations. Food Microbiol., 27, 413-417.
Sivakumar, N. et al. (2010), Partial Characterization of Bacteriocins produced by Lactobacillus acidophilus and Pediococcus acidilactici. Braz. Arch. Biol. Technol., 53, 1177-1184.

Sturme, M. H. J. et al. (2007), Making sense of quorum sensing in lactobacilli: a special focus on Lactobacillus plantarum WCFS1. Microbiol., 153, 3939-3947.

Toba, T.; Samant, S. K; Itoh, T. (1991), Assay system for detecting bacteriocina in microdilution wells. Letters in Appl. Microbiol., 13, 102-104.

Todorov, S. D. et al. (2010), Characterisation of an antiviral pediocin-like bacteriocin produced by Enterococcus faecium. Food Microbiol., 27, 869-879.

Todorov, S. D.; Dicks, L.M.T. (2009), Effect of modified MRS medium on production and purification of antimicrobial peptide ST4SA produced by Enterococcus mundtii. Anaerobe, 15, 65-73.

Todorov, S. D. (2008), Bacteriocin Production by Lactobacillus plantarum AMA-K Isolated from Amasi, a Zimbabwean Fermented Milk Product and Study of the Adsorption of Bacteriocin AMA-K to Listeria sp. Braz J. Microbiol., 39, 178-187.

Todorov, S. D. et al. (2007), Partial characterization of bacteriocin AMA-K, produced by Lactobacillus plantarum AMA-K isolated from naturally fermented milk from Zimbabwe. Food Control, 18, 656-664.

Vaara, M. (1992), Agents that Increase the Permeability of the Outer Membrane. Microbiol. Rev., 56, 395411.

Zhao, S. et al. (2007), Characterization of multidrug resistant Salmonella recovered from diseased animals. Veterinary Microbiol., 123, 122-132.

Received: April 05, 2010; Revised: September 03, 2010; Accepted: April 25, 2011. 